\title{
Kobiecość przekształcona. Indyzacja i europeizacja kobiety w strefach kontaktu na przykładzie malarstwa miniaturowego XVI-XIX w.
}

\section{Wstęp}

Drzedmiotem artykułu jest analiza adaptacji wyobrażeń kobiet i moty-
wów europejskich w indyjskim malarstwie miniaturowym o tematyce kobiecej tworzonym pod patronatem władców muzułmańskich oraz hinduskich w okresie od XVI do XIX w. Termin „strefa kontaktu” (contact zone) został zaproponowany przez Mary Louise Pratt w jej książce Imperial Eyes: Travel Witing and Transculturations ${ }^{1}$ dla określenia przestrzeni zetknięcia się kultur, w której geograficznie i historycznie odległe ludy kontaktują się ze sobą i nawiązuja relacje. Autorka stwierdza, że przywołuje ona przestrzeń i czas, w których poprzednio rozdzielone podmioty koegzystuja, a ich tory przecinają się․ Pratt odnosi swoje rozważania do tekstów z okresu kolonizacji. W mojej opinii perspektywa strefy kontaktu daje duże możliwości również w obszarze historii sztuki oraz relacji i postrzegania płci. Jak stwierdza Pratt, optyka ta uwypukla to, w jaki sposób ludzie mu poddani sa

1 M. L. Pratt, Imperial Eyes: Travel writing and Transculturation, 1992, 2008 [wydanie polskie: Imperialne spojrzenie. Pisarstwo podróżnicze a transkulturacja, Kraków 2011).

2 Ibidem, s. 26-27. 
kształtowani przez swe wzajemne relacje; rozpatruje je pomiędzy dwoma cywilizacjami nie w kategoriach odrębności, odseparowania lecz współobecności, interakcji, zazębiającego się rozumienia i działania ${ }^{3}$. Idąc tym tropem, można się zastanowić, jak artysta kształtuje swoją twórczość w kontakcie z zupełnie mu obca tradycja, jak ja odbiera, interpretuje oraz przekształca. Analizując zagadnienia wpływu kobiet i motywów europejskich na ikonografie kobiet indyjskich, mamy do czynienia z dwoma poziomami kontaktu międzykulturowego: artystycznego i płciowego, które zazębiaja się ze soba. Idąc dalej, kontakt ten nie musi być stały, niezmienny, istotne jest również to, jak wpływał on na postrzeganie rzeczywistości i zmieniał optykę, kiedy nie było chwilowo bezpośrednich relacji. Interesujące jest trwanie i przekształcanie form powstałych pod wpływem bezpośredniego kontaktu. Rozpatrywać go też należy na wielu poziomach, w tym pośredniego kontaktu, za jaki można uznać styczność tylko wytworami obcej cywilizacji, bądź nawet już z ich adaptacjami dokonanymi na miejscowym gruncie.

W literaturze poświęconej kolonializmowi dużą uwagę poświęca się perspektywie zachodniej, w tym kwestiom, w jaki sposób kolonizujące nacje tworzyły konstrukty „obcego” i jakie stosowały wobec niego strategie. Literatura feministyczna natomiast podkreśla, że to kobieta jest tą „obcą” w opozycji do mężczyzny. W perspektywie badań nad kolonializmem kobieta „wschodnia” zyskiwała więc podwójną obcość: poprzez płeć oraz fakt pochodzenia $z$ terenów poddanych kolonizacji. Optyka contact zone, jak wspomniano, kładzie nacisk na wzajemne relacje, a nie tylko punkt widzenia kolonizatora. Problem przedstawień kobiet powstałych w wyniku inspiracji europejskich $\mathrm{w}$ malarstwie indyjskim kładzie nacisk na indyjską reakcję na kontakt z obcą cywilizacja i obca kobietą.

W kontekście omawianej tematyki ważna jest również takie kwestie, jak: płeć artysty, rodzaj mecenatu oraz pozycja kobiet. Profesjonalnymi artystami byli mężczyźni, natomiast kobiety, o ile w ogóle malowały, zajmowały się tym amatorsko. Niektóre $z$ nich były jednakże bardzo utalentowane i osiagały dużą biegłość w malarstwie miniaturowym. I choć niewiele za-

3 Ibidem, s. 27. 
chowało się świadectw ich działalności artystycznej, to jednak są one istotne np. dla portretu kobiecego.

Mecenasami malarstwa miniaturowego byli głównie władcy, którzy patronowali pracowniom na swoich dworach. Ich wybory oraz zapotrzebowanie na określone rodzaje dzieł wpływały na rodzaj podejmowanej tematyki. Zdarzały się jednak sytuacje, kiedy damy dworu również zamawiały u artystów dzieła. Kobiety dworskie, które niekiedy również patronowały malarstwu, zlecały ten sam rodzaj tematyki, co wpływało na utrzymywanie się tradycyjnej ikonografii kobiet ${ }^{4}$.

Istotny dla przedstawień kobiet jest również fakt, że żyły one w zamkniętej przestrzeni (purdah), do której wstęp miał jedynie panujący. Artyści nie znali więc najczęściej ich powierzchowności. Oprócz tego kobiety, a szczególnie te wysoko urodzone należało przedstawiać zgodnie z typem idealnym. Obrazy ukazuja zatem raczej konstrukty kulturowe kobiet oraz męskie wyobrażenia na ich temat.

Wybrane ramy czasowe mogą wydawać się dyskusyjne, jeśli chodzi o zagadnienie kolonizacji. W mojej opinii, za początek procesu kolonizowania Indii przez Brytyjczyków można uznać powstanie East India Company (1600), a następnie przybycie na dwór cesarza Dźahangira (1569-1627) ambasadora króla Jakuba I (1566-1625) - sir Thomasa Roe (1581-1644, w Indiach przebywał w latach 1615-1618) ${ }^{5}$. Wydarzenia te rozpoczęły proces przybywania do Indii Brytyjczyków i stopniowe zyskiwanie wspływów oraz przejmowanie władzy nad tym krajem. Kolonizacja europejska przebiegała na wielu rozmaitych poziomach, w tym na obszarze sztuki. W tej kwestii ważne będą również kontakty z Portugalczykami, których obecność oraz dary w postaci dzieł plastycznych były istotne dla kolonizacji przestrzeni artystycznej. W okresie od XVI do XIX wieku mamy do czynienia z procesem, który można określić jako początek kolonizacji, niejako przyglądanie się wzajemne obu cywilizacji. W interesujacym nas obszarze sztuki i percepcji kobiet oraz

4 M. E. Aitken, Pardah and Portrayal: Rajput Women as Subjects, Patrons, and Collectors, „Artibus Asiae" 2002, vol. 62, no. 2, s. 264.

5 Pierwszym ambasadorem na dworze Dźahangira był William Hawkings (ok. 1585-1613), jednakże jego misja nie osiągnęła zamierzonych celów, dopiero misja Roe zakończyła się sukcesem i cesarz zapewnił ochronę faktorii Kompanii Wschodnioindyjskiej. 
sztuki europejskiej kontakty te nie były często bezpośrednie, szczególnie jeśli chodzi o styczność z kobietami z Europy. Niewiele z nich przybywało wówczas do Indii ${ }^{6}$ a mężczyźni europejscy często wchodzili w relacje z miejscowymi kobietami ${ }^{7}$. Artyści indyjscy znali więc europejskie kobiety głównie z dzieł europejskich bądź już recepcji miejscowych i postrzegali je przez ich pryzmat oraz poddawali interpretacji. $\mathrm{Na}$ ich podstawie tworzyli też własne wyobrażenia. Wielokrotnie wizerunki te dostosowywano do własnych wyobrażeń i przekształcano według uznania.

Analizowane dzieła łączy podstawowa kwestia - powstały one dla odbiorcy miejscowego, a nie kolonizatora. Ukazują one reakcje miejscowego artysty dla miejscowego patrona. Sytuacja bowiem ulega zasadniczej zmianie, kiedy artyści zatrudniani byli dla brytyjskich patronów i tworzyli dzieła, które musiały odpowiadać ich gustom. Doprowadzało to do sytuacji, kiedy sami siebie postrzegali wedle kategorii obcych, tworząc obrazy, dla których zastosować można określenie Pratt - autoetnografię ${ }^{8}$. Do kategorii tej będą należały głównie dzieła tradycyjnych twórców, określane mianem Company Painting.

Za pierwszy oficjalny kontakt z Europejczykami na dworze mogolskim uznaje się spotkanie cesarza Akbara (1542-1605) z jezuitami w 1572 w Cambay. Jednakże wpływy europejskie docierały na dwór mogolski na długo przed tym wydarzeniem. Kroniki cesarza Humajuna (1508-1556) wzmiankuja o tekstyliach europejskich eksponowanych na dworze, natomiast Abu'l Fazl napisał, że ,nieożywione obiekty w dziełach sztuki europejskiej wydaja się być [!] żywe" . Niemniej jednak to dopiero Akbar jako pierwszy na taką skalę interesował się malarstwem europejskim. Podczas spotkań z Jezuitami otrzymywał dary, w tym dzieła sztuki. Cesarz je bardzo podziwiał, a szczególnie wizerunki Madonny

6 Więcej na ten temat zob.: J. Mickelson-Gaughan, The 'Incumberances': British Women in India, 1615-1856, New Delhi 2013.

7 Więcej na ten temat zob. D. Ghosh, Sex and the family in colonial India: the making of empire, Cambridge 2006.

8 M.L. Pratt, op.cit., s. 27-28.

9 M. C. Beach, Mughal and Rajput Painting. (The New Cambridge History of India, vol. I, part 3), Cambridge 1992, s. 52-55. 
z Dzieciątkiem ${ }^{10}$. Od tego czasu coraz więcej obrazów spoza Indii pojawiało się na mogolskim dworze. Sir Thomas Roe, który wiedząc o zamiłowaniu cesarza do sztuki, ofiarował Dźahangirowi znaczną kolekcję prac twórców europejskich. Jak jednak zauważył, władca posiadał wcześniej obrazy pochodzące z Anglii, takie jak „obrazy króla Anglii, Królowej, lady Elizabeth, hrabin Sommersett i Salisbury, oraz żony mieszkańca Londynu, Sir Thomasa Smytha, zarządcy East India Company" ${ }^{11}$. Jak zatem widoczne jest na podstawie tego opisu, wśród licznych prac europejskich docierających na dwór mogolski od niemal początków znajdowały się również wizerunki kobiet. Od czasów Aurangzeba (1618-1707) twórczość pracowni zaczyna podupadać i wielu artystów szukało schronienia w lokalnych ośrodkach, takich jak Lucknow and Murshidabad, przyczyniając się do ich rozkwitu (styl nazywany bywa prowincjonalnym mogolskim) czy na dworach władców dekańskich (Ahmednagar, Bijapur, Golconda). W szkołach dekańskich wpływy europejskie pojawiły się dwutorowo. Z jednej strony malarstwo to powstawało tam pod silnym wpływem mogolskim, a z drugiej władcy utrzymywali również bezpośrednie kontakty z Portugalczykami z Goa ${ }^{12}$, są też świadectwa, że przebywali tam podróżnicy innych nacji, jak np. Ludovico de Varthema (ok. 1470-1517). Mieli więc możliwość zaznajomienia się z Europejczykami, oryginałami prac pochodzącymi z Europy oraz już ich interpretacja pochodząca z cesarskiej pracowni.

$\mathrm{Na}$ terenie Radżasthanu można zauważyć analogiczną sytuację. Wiele szkół malarskich powstało pod bezpośrednia inspiracja malarstwa mogolskiego, stąd duże wpływy tamtej pracowni na miejscowa twórczość. Podobnie jak w pracowniach dekańskich - tam również docierały przedstawienia europejskie. Rzadziej jednak niż na dwór mogolski czy władców dekańskich przybywali tam sami Europejczycy. Wpływy europejskie miały więc bardziej charakter pośredni, co wpływało też na postrzeganie ich w kategoriach swoistego kuriozum i wpływało na sposób ich ukazywania.

10 G. Shahani and B. Charry, Emissaries in Early Modern Literature and Culture: Mediation, Transmission, Traffic, 1550-1700, Farnham 2009, s. 55.

11 Sir T. Roe, Sir W. Foster (ed.), The embassy of Sir Thomas Roe to the court of the Great Mogul, 1615-1619, as narrated in his journal and correspondence, vol. II, London 1899, s. 143.

12 K. Chaitanya, A History of Indian Painting - Manuscript, Moghul and Deccani Traditions, New Delhi 1979, s. 82. 
Obrazy europejskie ukazujące kobiety docierające do Indii można podzielić na kilka głównych grup tematycznych. Pierwszą stanowiły dzieła religijne, ukazujące często Madonnę z Dzieciątkiem, drugie to alegorie i sceny rodzajowe, a trzecie to portrety. Musiały niewątpliwie one wzbudzać duże zainteresowanie artystów z wielu powodów. Po pierwsze, ukazywały kobiety egzotyczne, o intrygującej fizjonomii i zupełnie innych strojach, po drugie, technika, w której były one przedstawione dawała duże możliwości artystyczne dla twórców, a po trzecie - nieznana w większości tematyka, która powodowała często odmienne od zamierzonych przez autora pierwowzoru interpretacje. Analizując prace ukazujące wizerunki kobiet europejskich, bądź na nich wzorowane, można zaobserwować następujący proces ich asymilacji na gruncie indyjskim: zaznajamianie się z obcą kobiecością i techniką poprzez kopiowanie, następnie adaptacja ich do indyjskiej tematyki oraz indyzacja kobiety europejskiej i stworzenie na jej podstawie nowego typu kobiety indyjskiej. Wizerunki kobiet europejskich wpłynęły również na sposób ukazywania kobiet indyjskich. Kontakt ten miał zatem dwa główne wymiary - kobietę europejska poddano indyzacji, natomiast indyjska - europeizacji.

\section{Indyzacja kobiety europejskiej}

\section{Kopiowanie}

Artyści indyjscy wielokrotnie wykonywali dokładne kopie przedstawień kobiet europejskich. Była to jedna z pierwszych reakcji na kontakt z obca kobiecością jak i obca techniką. Kopiując dokładnie, mieli możliwość poznania wyglądu oraz sposobu odtwarzania rzeczywistości charakterystycznych dla odmiennej cywilizacji. Wśród licznych prac tego typu szczególne znaczenie miały wizerunki Matki Boskiej, alegorii czy scen rodzajowych. Portrety kobiet europejskich, jak wyżej wspomniano, cieszyły się również dużym zainteresowaniem. Sam cesarz Dźahangir zamawiał wielokrotnie ich kopie. Jak możemy domniemywać ze wspomnień Roe, portret jego świeżo poślubionej małżonki miał nazywać największym skarbem i wyrażał się z uznaniem dla piękna obrazu - w tym oczywiście ukazanej 
kobiety $^{13}$. Widocznej jest tu zainteresowanie nowością, egzotyką oraz męskie zainteresowanie kobiecością. Portrety kobiet europejskich intrygowały również mieszkanki królewskiego haremu, na których specjalną prośbę cesarz polecał wykonywać kopie tych dzieł. Tworząc je, artysta dokonywał pierwszego etapu przekształcenia - kobieta europejska przedstawiana była przez artystę pochodzącego z zupełnie innego kręgu kulturowego. Niekiedy były to bardzo dokładne wizerunki, do tego stopnia, że sam Roe nie mógł rozpoznać, które z zaprezentowanych mu dzieł jest oryginałem, a które kopią.

Nie zawsze to jednak musiały być skończone dzieła, wykonane dla szerszego odbioru. Artyści niekiedy też robili wprawki artystyczne, kopiując fragmenty dzieł europejskich, ukazujących kobiety. Zachowane szkice tego typu są bardzo interesujące, szczególnie gdy na jednym kawałku papieru przedstawione są kobiety indyjskie i europejskie. Indyjskie ukazywane sa według schematu charakterystycznego dla danej pracowni, natomiast Europejki w różnych pozach. Może autor poszukiwał odpowiedniego wzorca, który mógłby potem stosować w obrazach? A może jedynie eksperymentował z nowym typem kobiecości i techniką?

\section{Farangi}

Niekiedy jednak artyści mieli duże problemy z naśladowaniem obcej techniki i obrazy te sa dalekie od europejskiego oryginału. Modelunek staje się płaski, a mimika twarzy jest przesadnie zaznaczona. Wiele dzieł przedstawia europejskie kobiety, jednakże trudno określić, czy powstało na podstawie oryginalnej pracy, czy też wielokrotnie już wcześniej powielanej i modyfikowanej. Z czasem bowiem postacie te zaczęły funkcjonować w oderwaniu od łatwo rozpoznawalnego wzoru i określa się je terminem farangi, którym ogólnie nazywano Europejczyków. Termin farangi w odniesieniu do ikonografii postaci kobiety europejskiej można stosować, opisując przedstawienie, w którym źródło inspiracji pozostaje nieznane lub sa one bardzo odległe od europejskiego pierwowzoru (il. 1,2). Równie dobrze też artysta mógł mieć jedynie w pamięci wizerunek Europejki i luźno się nim zainspirować,

13 Sir Thomas Roe, Sir William Foster (ed.), op.cit., vol. I, s. 254-255. 
zachowując jednak wszystkie elementy europejskie takie jak rysy twarzy, strój, sposób ujęcia (głowa najczęściej 3/4) (il. 3).

\section{Indyzacja detalu - indyzacja kontekstu - indyzacja kobiecości}

Wizerunki kobiet europejskich poddane zostały szybko indyzacji, która przejawiała się na dodawaniu lokalnych detali, umieszczaniu $\mathrm{w}$ indyjskim kontekście czy też zmianie fizjonomii z zachowaniem postawy i niektórych detali zaczerpniętych z pierwowzorów europejskich.

$\mathrm{Na}$ pierwszym etapie proces indyzacji wizerunków kobiet europejskich polegał na umieszczaniu ich w ozdobnych ramach, charakterystycznych dla dzieł mogolskich tego czasu. Niekiedy dodawano elementy, które sugerowały ujęcie okienne, zaznaczając u góry podwiniętą kotarę ${ }^{14}$. W portretach tych dokładnie oddawano szczegóły twarzy, strojów i biżuterii, naśladując jednocześnie europejskie techniki. Coraz częściej jednak same kopie stawały się obiektem kopii i stopniowo zmieniała się ich stylistyka oraz podpisy. Ta sama kobieta była wcześniej Lady Shirley (il. 4), by potem, w nieco zmienionej stylistyce figurowała jako Portugeese Lady ${ }^{15}$. Z czasem zaczęto je również przekształcać w lokalnym duchu stylistycznym oraz ikonograficznym - modelunek staje się bardziej płaski, a kobiecie niekiedy dodaje się czarkę i butelkę (il. 5). Cały czas jednak widoczny jest pierwowzór, szczególnie w ujęciu $3 / 4$ czy też stroju.

Kobiety europejskie dostosowywano niekiedy do lokalnego poczucia piękna poprzez ozdabianie ich w indyjski sposób - dodając elementy stroju bądź częściej biżuterię. Stawała się ona wówczas bardziej atrakcyjna dla indyjskiego artysty i odbiorcy, zachowując jednak cały czas walor egzotyki.

Wizerunki kobiet europejskich umieszczane były też w indyjskich kontekstach. Niekiedy były to niewielkie przekształcenia, polegające na umiesz-

14 Portrety okienne określa się terminem d乏́harokha, stosowany był on głównie do portretów, w którym osoba ukazywana była w oknie, natomiast na parapecie przedstawiany był dywan, więcej na ten temat w dalszej części artykułu.

15 Portuguese lady, szkoła mogolska, XVII w., Bibliotheque Nationale Paris (fol. V. 6200). 
czeniu ich w indyjskim pejzażu ${ }^{16}$. Obrazy takie mogły ukazywać też kopie postaci kobiecych zaczerpnięte $z$ europejskich pierwowzorów podczas indyjskich rytuałów, np. oddawania czci słońcu ${ }^{17}$ lub nawet jako bohaterki lokalnych historii (np. Laila i Majnun) ${ }^{18}$. Czasem też modyfikowano ich wygląd, uwzględniając własne wyobrażenia na temat prawdziwego wizerunku kobiet z Europy, np. na kopii obrazu europejskiego ${ }^{19}$ dodano kobiecie nakrycie głowy, który popularny był wówczas na dworze cesarskim, oraz butelkę i czarkę w typie lokalnym. Częściej jednak kobieta europejska zyskiwała już nieco zindyzowaną formę - to jest postać jej w ogólnym stylu danej pracowni malarskiej, jednakże zachowują europejskie cechy fizjonomiczne ${ }^{20}$. Artyści wyobrażali ją często w pozach i sytuacjach charakterystycznych dla księżniczek (np. na tarasie pałacowym) lub też w tradycyjnej ikonografii (np. z papuga, z czarka). Niekiedy jednak nowa postać skłaniała do nowej ikonografii. Ciekawym przykładem takiego wyobrażenia jest Europejka podczas łowienia ryb ${ }^{21}$.

Europejki ukazywano również $\mathrm{w}$ parach $\mathrm{z}$ mężczyznami. Istniało wiele wariantów tego typu wyobrażeńn ${ }^{22}$. Mogły to być przedstawienia w całości kopiowane z europejskich pierwowzorów, zachowując wszystkie cechy oryginału, niekiedy też artysta przekształcał je zgodnie z własnym duchem. Ciekawym przykładem drugiego z wymienionych typów dzieł jest obraz ukazujący Ludwika XV z damą (il. 6). Miniatura jest podpisana, kobietę określono jako sankhani - to jest jeden z typów kobiet, który np. w Anangaraga $a^{23}$ charakteryzowany jest następująco: „jej skóra jest zawsze gorąca

16 Zob. na przykład: Son Prakash Verma, „La'l: the Forgotten Master”, Mughal Masters, Further Studies, Asok Kumar Das (ed.), Mumbai 1998, 81-82.

17 Gulshan Album, przypisywany Basawanowi (aktywny ok. 1556-1600), ok. 1590-1995, pracownia mogolska w Lahore lub Delhi, Museum of Islamic Art, Doha.

18 Szkoła mogolska, 1595-1600 r., Chester Beatty Library (Linda York Leach, Mughal and other Indian paintings from the Chester Beatty Library, vol. 1, London 1995, 1.240).

19 Gitanjali Shahani, Brinda Charry, Emissaries in Early Modern Literature and Culture: Mediation, Transmission, Traffic, 1550-1700, Farnham 2009, s. 70.

20 Np. kobieta z klatka, Udaipur, ok. 1720 r. The British Museum (1956,0714,0.28).

21 Zbiory prywatne, Uniara, ok. 1760 r.

22 Zob. na przykład: J.P. Losty, A Prince's Eye Imperial Mughal Paintings from a Princely Collection Art from the Indian Courts, London: Francesca Galloway 2013, s. 52.

${ }^{23}$ Tekst z gatunku kamaśastr powstały ok. XV-XVI w. 
i śniada lub żółto-brązowa, jej ciało jest duże, talię ma szeroką piersi małe, jej twarz jest pociagła, dłonie i stopy szczupłe i długie, spogląda spod oka, zachwyca się strojami, kwiatami i ozdobami w kolorze czerwonym. Namiętność miłosna, na która jest bardzo podatna, rozpala jej głowę i miesza rozum, spazm rozkoszy każe jej wbijać paznokcie w ciało męża, ma temperament choleryczny, mało czuły, zuchwały, butny, złośliwy, wybuchowy i gwałtowny, bywa też okrutna"24. Indyjski odbiorca, postrzegając ja własnych kategoriach estetyczno-kulturowych, zakwalifikował ja do jednego z najmniej pociagających typów kobiet. Nie odzwierciedlała ona bowiem ideału - to jest padmini - zgodnie z którym prezentowano kobiety indyjskie. Ciemniejsza skóra, wynikła z naśladowania obcej techniki, oraz proporcje jej ciała nieodpowiadające indyjskim ideałom piękna, kazały widzieć w niej śankhini - mało atrakcyjną fizycznie i pełna pożądania seksualnego. Kobiety europejskie - malowane z odsłoniętymi piersiami, otwarcie pozujące obcym mężczyznom, których przestrzenie życiowe nie były oddzielone i mogły przebywać w towarzystwie nieznanych sobie mężczyzn - odbierane były często przez Indusów jako bezwstydne i zdeprawowane.

Istniało również wiele wyobrażeń, na których artysta swobodnie zestawiał postaci Europejczyków, posiłkując się podczas przedstawiania kobiety i mężczyzny innym dziełem, czasem dodając im lokalnego kolorytu. Niekiedy też malował ich zgodnie z ikonografia tradycyjna, jak np. w portrecie okiennym ${ }^{25}$ czy też nawet w scenach erotycznych ${ }^{26}$.

Opieranie się na kilku źródłach inspiracji, przy jednoczesnej indyzacji przedstawienia dawało niekiedy zaskakujące efekty, na przykład jak w obrazie Wiktoria Maharaniego z dzieckiem (il. 7) Artysta bazował tu na wzorcu ikonograficznym Matki Boskiej z Dzieciątkiem, posłużył się też wizerunkiem królowej. Nieznajomość realiów panujących w Europe doprowadziła

24 The Ananga Ranga. Translated by Sir Richard F. Burton, edition created and published by Global Grey 2013, s. 6; zob. też: D. Kamińska, Wizerunek kobiety w malarstwie miniaturowym Indii XVI-XIX wieku, Warszawa 2007, s. 152-154.

25 Zob. na przykład: A. Topsfield, Ketelaar's embassy and the farangi theme in the art of Udaipur, „Oriental Art”, vol. XXX, no. 4, 1984/85, s. 359-360.

26 Zob. na przykład: Philip Rawson, Erotic Art of India, New York 1983, il. 35, 36; Illustrated Kama-Sutra Ananga-Ranga Perfumed Garden: The Classic Eastern Love Text (Classic Easton Love Texts), Translated by Sir Richard Burton and F.F. Arbuthnot, London: The Hamlyn Publishing Limited 1987, s. 75. 
do błędnych interpretacji i ukazania monarchini znanej ze swych purytańskich zasad $z$ nagim biustem. Co jednak warto podkreślić nawet przy tak silnej stylizacji twarzy artyście udało się uchwycić pewne podobieństwo do królowej.

Niekiedy w procesie oswajania obcej kobiecości, postacie Europejek zyskuja cechy indyjskie. Sa to dzieła w dużej mierze inspirowane obrazami europejskimi, jeśli idzie o technikę (np. chiaroscuro) czy kompozycję, natomiast zmienia się wygląd twarzy kobiety - zyskuje ona migdałowe oczy i mocno podkreślone łuki brwiowe ${ }^{27}$.

W interpretacji artystów indyjskich obca kobiecość uległa więc stopniowemu zindyzowaniu - nadal pozostając obca, otrzymała swoisty koloryt lokalny. Kobieta europejska, zatrzymana w czasie, zyskała nowy byt w odmiennej rzeczywistości.

\section{Europeizacja kobiety indyjskiej}

Zetknięcie tych dwóch kultur działało również w drugą stronę - kobiety indyjskie poddawano europeizacji. W tym wypadku również można rozpatrywać kilka rodzajów tego typu reakcji. Pierwszy z nich polegał na bezpośredniej inspiracji do tworzenia portretów kobiet indyjskich. W drugim z nich proces ten wyglądał analogicznie jak w przypadku indyzacji - kobiety indyjskie ukazywano w elementach strojów europejskich. Kolejny polegał na adaptacji europejskich typów ikonograficznych do własnych potrzeb, szczególnie Madonny z Dzieciątkiem. Niekiedy też artyści inspirowali się jedynie sposobem oddawania emocji na obrazach europejskich i starali się zastosować podobne zabiegi, oddając fizjonomię kobiet indyjskich.

\section{Portrety kobiet}

Portrety kobiet europejskich stały się zapewne bezpośrednią inspiracją do wykonywania portretów kobiet indyjskich. Zarówno w sztuce perskiej, jak

\footnotetext{
27 Zob. na przykład: Stuart C. Welch, Room for Wonder. Indian Painting during the British Period 1760 - 1880, New York: The American Federation of Arts 1979, il. 59.
} 
i wcześniejszej indyjskiej, kobiety ukazywane były według określonych kanonów i mimo że portret jako gatunek istniał, to nie polegał on na wiernym odtwarzaniu fizjonomii ${ }^{28}$.

Pierwszym znanym, pochodzącym z czasów mogolskich, przedstawieniem w którym kobiety prezentują rys indywidualny, jest miniatura obrazująca narodziny Dźahangira autorstwa Bishana Dasa ${ }^{29}$, gdzie ukazano wiele kobiet o bardzo zróżnicowanych fizjonomiach. Na obrazie tym kobiety stanowią część bardzo rozbudowanej sceny ${ }^{30}$. Od czasów Dźahangira zaczynaja także powstawać samodzielne wizerunki kobiet. Można je podzielić na kilka rodzajów. Pierwszy z nich stanowią dzieła ukazujące silnie zindywidualizowane fizjonomie, które sprawiaja wrażenie, że zostały wykonane na podstawie bezpośredniej obserwacji. Drugi typ to obrazy ukazujące postacie o wyglądzie bardzo do siebie zbliżonym, różniące się nieznacznie. Trzeci natomiast to dzieła prezentujące kobiety według typu idealnego, powielane z niewielkimi modyfikacjami detali.

Pierwszy z wymienionych typów jest bardzo interesujący, ukazuje bowiem prawdopodobnie prawdziwe fizjonomie kobiet. Wykazują one bardzo duży rys indywidualny, ponadto zastosowano w nim modelunek światłocieniowy $^{31}$. Forma medalionu, a taką niekiedy przybierają, może stanowić nawiązanie do portretów europejskich, w tym miniatur ukazujących kobiety. Jednymi z pierwszych tego typu dzieł były prace Isaaca Olivera (1565-1617), przywiezione przez jego kuzyna, Sir Thomasa Roe ${ }^{32}$. Jak wspomniano, obrazy te były kopiowane na życzenie cesarza, prawdopodobnie

28 Dyskusję na ten temat zob. P. Kaimal, The Problem of Portraiture in South India, circa 870-970 A.D., „Artibus Asiae”, vol. 59, no. 1/2 (1999), s. 59-133.

29 Ca. 16I0-1615, Museum of Fine Art, Boston,obraz ten był reprodukowany i omawiany wiele razy, zob. na przykład: A. K. Das, Bishandas: „Unequalled in his Age in Talking Likenesses, Mughal Masters, Further Studies, A. K. Das (ed.), Mumbai: Marg Publications 1998, s. 118-119 czy też: Molly Emma Aitken, op.cit., s. 249.

30 Co ciekawe, wiele $z$ dam przedstawionych na obrazie Bishan Das, pojawia się potem na samodzielnych portretach, co może potwierdzać hipotezę, że były to portrety mieszkanek zenany (Milo Cleveland Beach, op.cit., s. 95-96).

31 Zob. na przykład: szkoła mogolska, ok. 1660, The Cleveland Museum of Art, see: L. York Leach, Indian Miniature Paintings and Drawings. The Cleveland Museum of Art Catalogue of Oriental Art, (Part One), Cleveland: Cleveland Museum of Art 1986, s. 127.

32 Sir Thomas Roe, Sir William Foster (ed.), op.cit., vol. I, s. xxiv. 
więc stanowiły bezpośrednią inspirację dla dzieł indyjskich. Jako że obcym mężczyznom nie wolno było przekraczać progów zenany ${ }^{33}$, zastanawiające jest autorstwo tych obrazów. Jak jednak wcześniej wspomniano, kobiety niekiedy również zajmowały się malarstwem. Zachowało się kilka przykładów z czasów mogolskich dzieł wykonanych przez dworskie damy ${ }^{34}$. W zbiorach Bharat Kala Bhavan w Varanasi znajduje się natomiast miniatura przedstawiająca kobietę malująca portret innej mieszkanki kobiecej części pałacu ${ }^{35}$. Wydaje się więc bardzo prawdopodobne, że to właśnie one tworzyły tego typu wizerunki. Obrazy te były jednak wykonywane dla prywatnego ogladu i nie były eksponowane publicznie. Byłoby to bowiem pogwałceniem intymności żyjących w zenanach kobiet.

Działania takie spowodowały zaistnienie kobiety indyjskiej jako indywidualności, a nie tylko uosobienie typu idealnego. Pokonały więc nie tylko fizyczne bariery oddzielające je od męskiego świata, ale też i kulturowe, każące w nich widzieć uosobienia ideału. Choć nieliczne, stanowią więc bardzo ważną grupę dzieł, zarówno ze względu na aspekty społeczne, jak i artystyczne. Można więc powiedzieć, że portrety kobiet europejskich przyczyniły się do indywidualnego zaistnienia w sztuce kobiet indyjskich.

Drugi z wymienionych typów wzbudza kontrowersje wśród badaczy. Większość z nich sądzi bowiem, że są to wizerunki idealizowane, niebazujące na bezpośredniej obserwacji ${ }^{36}$. Pojawiają się jednak głosy, że postacie ukazane na tych obrazach różnią się jednak od siebie, co może stanowić dowód na to, że noszą one jednak cechy indywidualne ${ }^{37}$. Być może było to możliwe w niektórych przypadkach, że artyści widzieli bądź znali z opowieści cechy charakterystyczne niektórych dam dworu. Do takich mogła należeć Nur Dźahan (1577-1645), która miała bardzo duże wpływy na

33 Kobieca część pałacu.

34 Gitanjali Shahani, Brinda Charry, op.cit, s. 69.

35 Szkoła mogolska, ok. 1635-1640, V. N. Desai, Life at Court: Art for India's Rulers, 16th-19th Centuries, Boston: Museum of Fine Arts Boston 1985, s. 76; In the image of man: The Indian perception of the universe through 2000 years of painting and sculpture: Hayward Gallery, London, 25 March-13 June 1982: catalogue, London 1982, s. 136.

36 Zob. na przykład: O. C. Gangoly, On the authenticity of feminine portraits of the Moghul School, „Rupam”, no. 33-34, January/April 1928, s. 5-11.

37 Molly Emma Aitken, op.cit., s. 249-250. 
cesarskim dworze i często przełamywała konwencje każące jej pozostawać niewidoczna dla świata ${ }^{38}$. Być może więc niektóre wizerunki powstałe za jej życia noszą niektóre cechy jej wyglądu. Jeden z obrazów jest szczególnie intrygujący, ponieważ cesarzowa ukazana jest ze strzelba, pełna mocy, wyglądająca wręcz na pierwszy rzut oka jak mężczyzna ${ }^{39}$.

Jako kolejny przykład kobiety, której portrety noszą znamiona indywidualizmu, można wskazać Lal Kunwar, ukochaną żonę cesarza Dźahandara Śaha (1661-1713). W tym przypadku wpływ na przedstawienie jej cech wyglądu mógł mieć w pierwszym rzędzie fakt jej pochodzenia - była ona pierwotnie tancerka, tak więc jej aparycja była znana, a dopiero w następnej kolejności jej wpływy na dworze władcy. Kobiety najprawdopodobniej były więc siła decydująca o wyborze takiej konwencji, być może chciały, choć tylko w niewielkim stopniu, na ile było to możliwe, ukazać swoje oblicze szerszej publiczności i pozostać zapamiętaną na równi z mężczyznami.

Trzeci z wymienionych typów nie nosi znamion indywidualizacji i kobiety ukazywane są zgodnie z typem idealnym, różniąc się jedynie stylem danej pracowni artystycznej.

\section{Kobieta indyjska jako europejska dama}

Inspiracje strojem bądź ogólnym wyglądem kobiet europejskich pochodziły głownie z kilku źródeł. Pierwszym był kontakt z rzeczywistymi przedmiotami pochodzącymi ze Europy, drugi to dzieła sztuki, a trzeci, znacznie rzadszy, to bezpośrednie kontakty. Kobiety indyjskie miały styczność z obiektami europejskimi już w czasach Wielkich Mogołów. Wiele z rozmaitych darów, z którymi przybywali wysłannicy na dwór cesarski, przekazywana była następnie do žnany ${ }^{40}$. Szczególną popularnością wśród jej mieszkanek cieszyły się nakrycia głowy sprowadzane na ich specjalne zamówienie ${ }^{41}$. Kapelusze stanowią też najczęściej pojawiający się europejski

38 Więcej zob. Ellison Banks Findly, Nur Jahan, Empress of Mughal India, New York 1993.

39 Abu'l Hasan, 1612-1613 (Milo Cleveland Beach, op.cit., s. 96)

40 Ellison Banks Findly, op.cit., s. 149.

41 Letters Received by the East India Company from Its Servants in the East, F. Ch. Danvers (ed.), vol. II, 1613-1615, London 1897, s. 108-109. 
element stroju w przedstawieniach kobiet indyjskich. Wygląd Europejek oraz ich strojów był tak odmienny, że często funkcjonował jako swoiste kuriozum. Na obrazach spotyka się sytuacje, gdzie dama dworu zabawiana jest przez kobiety przebrane $\mathrm{w}$ rozmaite europejskie stroje, $\mathrm{w}$ tym nawet męskie ${ }^{42}$. Wydaje się, że stroje europejskie, zarówno damskie, jak i męskie była na tyle egzotyczne same w sobie, że niekiedy kobiety (bądź artysta) komponowali je dowolnie w jedną całość ${ }^{43}$.

Ubrania europejskie noszą też niekiedy postacie ukazane w typowo indyjskiej ikonografii i indyjskich wnętrzach. $\mathrm{Na}$ jednym z tego typu obrazów ukazano motyw występujący szczególnie w malarstwie XVIII-wiecznym - onieśmielona kobieta jest prowadzona na miłosne spotkanie do oczekującego na nią na łożu mężczyzny ${ }^{44}$. Zastosowanie strojów europejskich było swoista grą z egzotyka, elementem mającym uatrakcyjnić typowe przedstawienie.

Obiektem uwagi stawały się niekiedy włosy dam pochodzących spoza Indii, które inspirowały artystów do przedstawiania Indusek z rozpuszczonymi, jasnymi lokami. Wszystkie te elementy były selektywną reakcją na zetknięcie z odmienną kobiecościa, wybierano i przetwarzano poszczególne elementy według osobistego uznania, czy to zamawiającego dzieło, czy też artysty. Wielokrotnie też dochodziło do takiego przemieszania elementów europejsko-indyjskich, że niekiedy nie można precyzyjnie określić, czy prezentowana postać jest indyjską damą przebraną bądź ukazaną na europejski sposób, czy też Europejką w indyjskim kontekście. W obrazach tych doszło do połączenia tych dwóch, zdawałoby się tak odrębnych światów, w jedna postać.

Niekiedy wizerunek kobiety europejskiej był wzorcem, który po przeobrażeniu i połączeniu z innymi elementami, funkcjonował i rozwijał się już niezależnie od pierwowzoru. Interesującym przykładem takiej adaptacji jest postać wzorowana na alegorii poezji (il. 8). Twórca zapewne nie znał oryginalnego znaczenia dzieła i zainspirowało go jedynie półnagie popiersie. W jednym z pierwszych wersji zindyzowana postać alegoryczna poja-

42 Szkoła mogolska, 1742 r. (Vishakha N. Desai, op.cit., s. 82-83).

43 Portret kobiety, Radźasthan, XVIII w., The British Museum (1920,0917,0.13.7).

44 Szkoła mogolska, ok. 1700, The British Library, 1955,1008,0.17. 
wia się jako jeden z kilku motywów tematycznych umieszczonych wspólnie na jednej stronie manuskryptu (il. 9). Szybko jednak przedstawiona została ona samodzielnie, co więcej w typie portretowym nawiązującym do typu d乏́harokha. Ten rodzaj wizerunku wywodził się ze zwyczaju ukazywania się cesarza podczas darbaru w oknie ${ }^{45}$. Jak wykazał J.P. Losty, ten typ porteru miał europejskie źródła, składały się na niego wizerunki władców europejskich, głównie królowej Elżbiety I - jeśli chodzi o sposób przedstawiania postaci oraz parapet okienny przykryty dywanem, pojawiający się na wizerunkach Madonny z Dzieciątkiem i portretach wysoko sytuowanych osób w malarstwie europejskim XV i XVI w. ${ }^{46} \mathrm{~W}$ okresie panowania Aurangzeba zastosowano go również dla półnagiej postaci kobiecej, początkowo jednak jedynie z podciagniętą kotarą okienną i bez cesarskiego dywanu (il. 10). Stopniowo jednak i to zostało przełamane i dywan stopniowo pojawiał się na przedstawieniach kobiet, nawet nagich. Przedstawienie to stało się niezwykle popularne i było powielane w pracowni cesarskiej, a potem również przeszło do szkół dekańskich oraz radźpuckich (il. 11). Parapet z dywanem zatem - mający swe źródło w ikonografii europejskiej Matki Boskiej i szlachty, zastosowany następnie do oficjalnych wizerunków władców mogolskich, przeszedł kolejno do przedstawień wysoko sytuowanych kobiet, a ostatecznie nawet kurtyzan.

\section{Madonna zostaje indyjską matką}

Spośród europejskich dzieł dużą popularnością wśród artystów cieszyły się wizerunki Madonny. Początkowo jedynie kopiowane, stały się z czasem wzorem dla przedstawiania indyjskiej matki z dzieckiem. Niektóre z nich w sposób wyraźny nawiązuja do europejskich pierwowzorów - artysta kopiował kompozycję, szaty oraz styl europejski, zmieniając jedynie

\footnotetext{
45 J.P. Losty uważa, że do końca panowania Śaha Dźahana przynależny był jedynie cesarzowi. Trzeba jednak zauważyć, że już w okresie Dźahangir powstawały wizerunki kobiet w oknach, nie tak rozbudowanych jak na oficjalnych cesarskich, jednakże niekiedy sugerowano ujęcie okienne poprzez roletę w górnej części, czy nawet w dywan w dolnej.

46 J.P. Losty, The Carpet at the Window: a European Motif in the Mughal Jharokha Portrait, [w:] Indian Painting: Themes, History and Interpretations; Essays in Honour of B.N. Goswamy, edited by M. Sharma and P. Kaimal, 52-64. Ahmedabad: Mapin Publishing 2013.
} 
rysy twarzy. Niekiedy jednak luźno nawiązywał do europejskiego prototypu, wybierając z różnych dzieł odpowiednie elementy, tworząc własną, oryginalną wizję europejsko-indyjskiego macierzyństwa ${ }^{47}$.

Znaczna większość z nich to dzieła, z których zaczerpnięto inspirację co do wzajemnego układu postaci, relacji matki z dzieckiem (niekiedy dziecko ma wygląd europejski), natomiast zmieniając rysy twarzy, strój i ozdoby na miejscowy. Obrazy tego typu powstawały głównie w Radźasthanie.

\section{Indyjska kobieta - europejska ekspresja}

Artyści indyjscy, jak wspomniano wcześniej, często inspirowali się wybiórczo poszczególnymi elementami europejskich przedstawień. Jedną z cech obcego malarstwa, którą wielokrotnie uważali za interesująca, był sposób ukazywania emocji na twarzy. W sztuce indyjskiej emocje wyraża się bardziej za pomocą kontekstu niż grymasów twarzy. Oczywiście istnieją dzieła, które odbiegają od tradycyjnych, ponadczasowych wyrazów oblicza, ale najczęściej są to formy groźne bóstw bądź przedstawienia o wydźwięku komicznym. Sztuka europejska dawała przykłady szerokiego wachlarza wyrażania emocji. Artyści wielokrotnie bardzo umiejętnie kopiowali zmieniające się pod wpływem emocji oblicza. Niekiedy też przetwarzali je we własnym duchu stylistycznym, zaznaczając zmarszczki powodowane śmiechem czy płaczem liniami, niekiedy z niewielkim cieniowaniem (il. 12). Doprowadziło to do interesujących efektów, czasami sprawiając wrażenie postarzenia prezentowanej postaci, niekiedy nawet do efektu ocierającego się o komizm.

\section{Wiele kobiecości - jedna rzeczywistość}

Jak wspomniano, kobieta europejska była najczęściej odbierana jako „obca” i egzotyczna. Podobnie było z przedstawicielkami innych nacji, takimi jak np. Chinki. Artyści niekiedy łączyli je bez większego zrozumienia tematu

\footnotetext{
47 Zob. na przykład: D. Mason, B. N. Goswamy, Intimate Worlds: Indian Paintings from the Alvin O. Bellak Collection, Philadelphia 2001, s. 156-157.
} 
na jednym przedstawieniu, gdzie kilka obcych nacji egzystowało w tej samej rzeczywistości. Jednym z niezwykłych obrazów tego typu jest przedstawienie dwóch chińskich kobiet ukazanych w europejskiej scenerii, rodem najprawdopodobniej z Francji. Na innym z kolei dwie eleganckie chińskie kobiety ukazano w anglo-indyjskim domu, siedzące na europejskich krzesłach. Co ciekawe, nad ścianie tuż za damami ukazano portrety europejskie, jakby sugerując, że sa to przodkowie czy członkowie ich rodziny. Dla artysty obie te nacje były do tego stopnia obce, że połączył je w jedną całość. W jednej, wyobrażonej przez artystę egzotycznej rzeczywistości funkcjonuja więc odrębne nacje - francuska, brytyjska i chińska, tworząc niezwykła całość, świat odrębnych „obcych”.

\section{Konkluzja}

Kontakty z europejską kobiecością w okresie od XV do początków XIX stulecia miały głównie charakter pośredni. Przyczyniło się do rozmaitych interpretacji, sposobów ich postrzegania oraz prób zrozumienia. Bardzo szybko kobieta europejska została niejako wchłonięta i przekształcona w indyjska rzeczywistość. Funkcjonowała głównie jako osobliwe kuriozum, które niekiedy zestawiano na tej zasadzie z kobietami z innych kręgów kulturowych. Różne też aspekty inspirowały twórców z odmiennych środowisk. I tak na przykład w sztuce mogolskiej nie zaadaptowano wizerunku Madonny z Dzieciątkiem do przedstawień świeckich. Może to wynikać z faktu, że Matka Boska była obdarzana szacunkiem jako matka jednego z proroków islamu. Dla wyznawców hinduizmu jednak nie miały te przedstawienia wydźwięku religijnego i przemawiały do kultury, w której macierzyństwo odgrywa bardzo dużą rolę w życiu kobiety oraz całego społeczeństwa. Często starano oddać nastrój tych obrazów - więź łącząca matkę i dziecko, niekiedy uwidaczniające się w zastosowanej technice - naśladowanie chirascuro, a niekiedy na próbach odtworzenia mimiki twarzy, co doprowadzało do niezamierzonego efektu komicznego. Co jest interesujace, obrazy europejskie oraz przedstawienia kobiet kopiowano przez krótki okres, jakby zaznajamiając się jedynie z obcą techniką i tematyką. Szybko wybrano aspekty interesujące twórców i przekształcono je we własnym 
duchu. Okres ten jest więc bardzo interesujący z punktu widzenia współistnienia tych dwóch nacji - europejskiej i indyjskiej w początkowej fazie kolonializmu. Kobieta i sztuka europejska, choć obca, łatwo wtopiła się w indyjską rzeczywistość. Paradoksalnie, pojawienie się w dużej liczbie realnych kobiet w Indiach i możliwość ich poznania, choćby powierzchownego, było jednym z czynników, które doprowadziło później do oddalenia się tych dwóch nacji.

\section{Summary}

\section{Femininity transformed. Indianisation and Europeanisation in the contact zones as seen in Indian miniature painting from the 16 th-19th centuries}

The subject of the article is an analysis of how images of European women were adapted in Indian miniature painting created under the patronage of Muslim and Hindu rulers during the period from the 16th to the 19th century. The term contact zone was used to identify areas where two cultures - in this case, Indian and European - met and the interactions between them. This would seem relevant for a analysis of these complex multicultural relations and this article will focus on two issues - art and gender. The analysed works bring together some fundamental issues - they were created for a local recipient, not the coloniser. Therefore, they reveal the reactions of a local artist created for a local patron. By analysing the representations of European women, or those modelled on them, one may observe the following process of their assimilation into an Indian form: familiarsing themselves with a foreign femininity and technique by copying and then adapting it to an Indian theme and then the Indianisation of European women and the creation on this basis of a new type of Indian woman Images of European women also affected how Indian women were portrayed. So this contact had two main dimensions - European ladies were subjected to Indianisation, while the Indians underwent a kind of Europeanisation. 


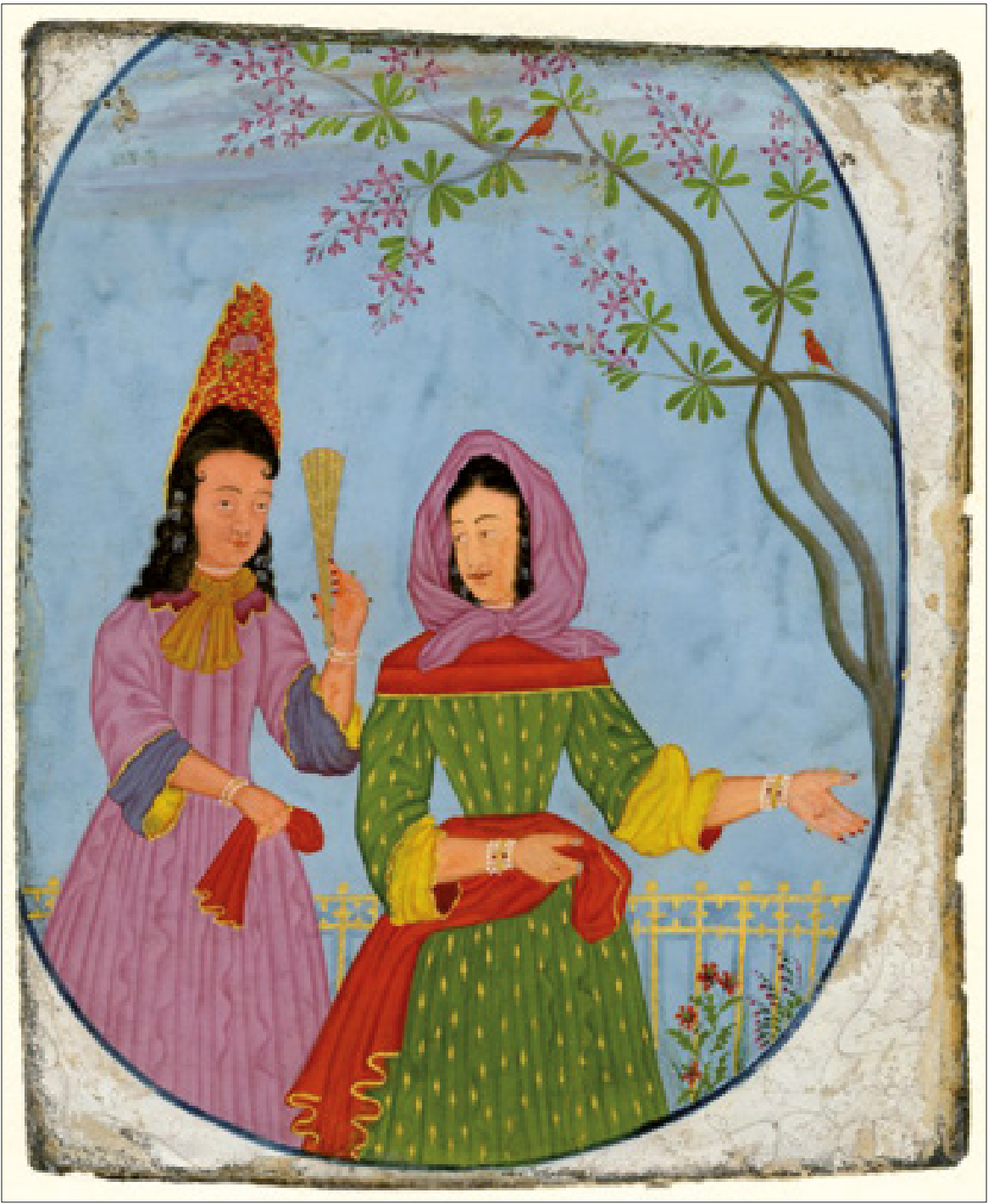

1. Dwie kobiety europejskie we francuskich strojach, Udaipur, ok. 1720, (C) Trustees of the British Museum (1956,0714,0.26) 


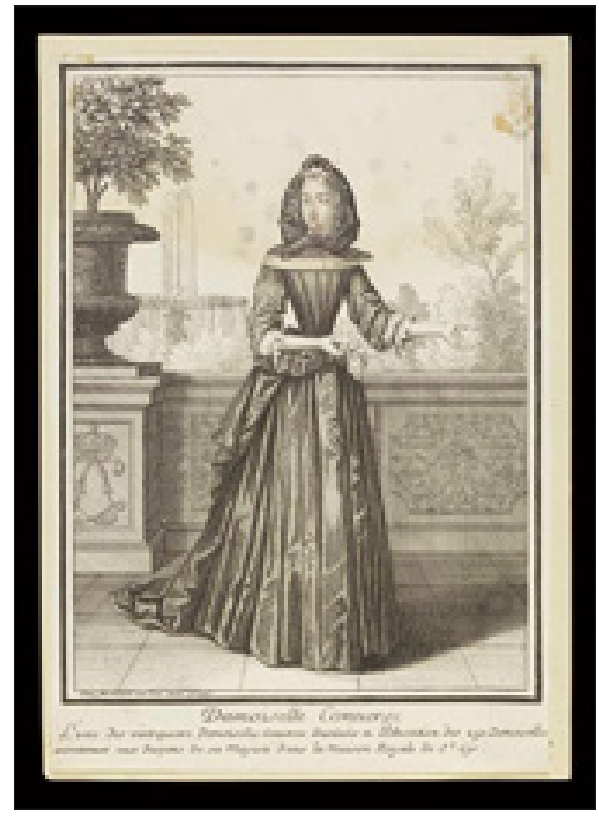

2. Damoiselle Converse, Henri Bonnart II, (1637-1711), C) Victoria and Albert Museum, London (E.21379-1957)

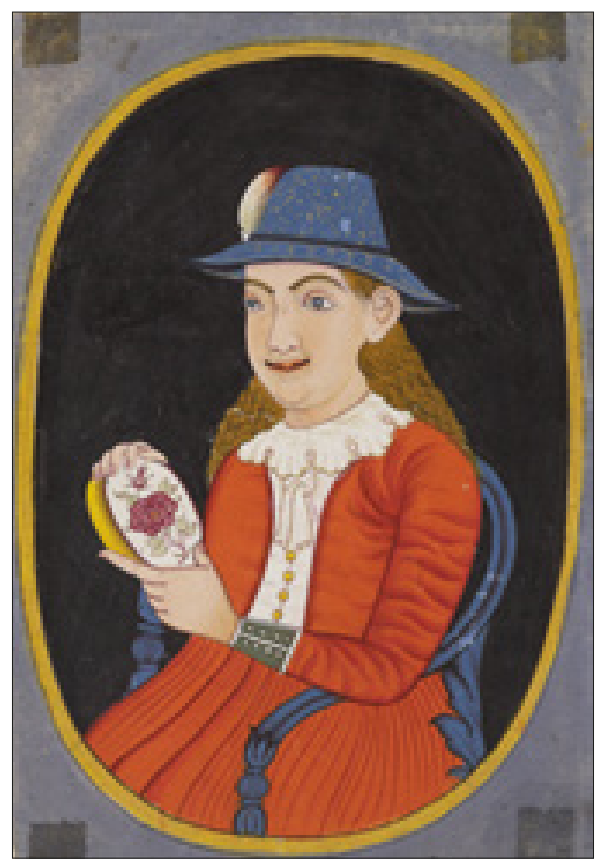

3. Kobieta europejska, Radźasthan, Udaipur, XVIII - XIX w. C Ashmolean Museum, University of Oxford 


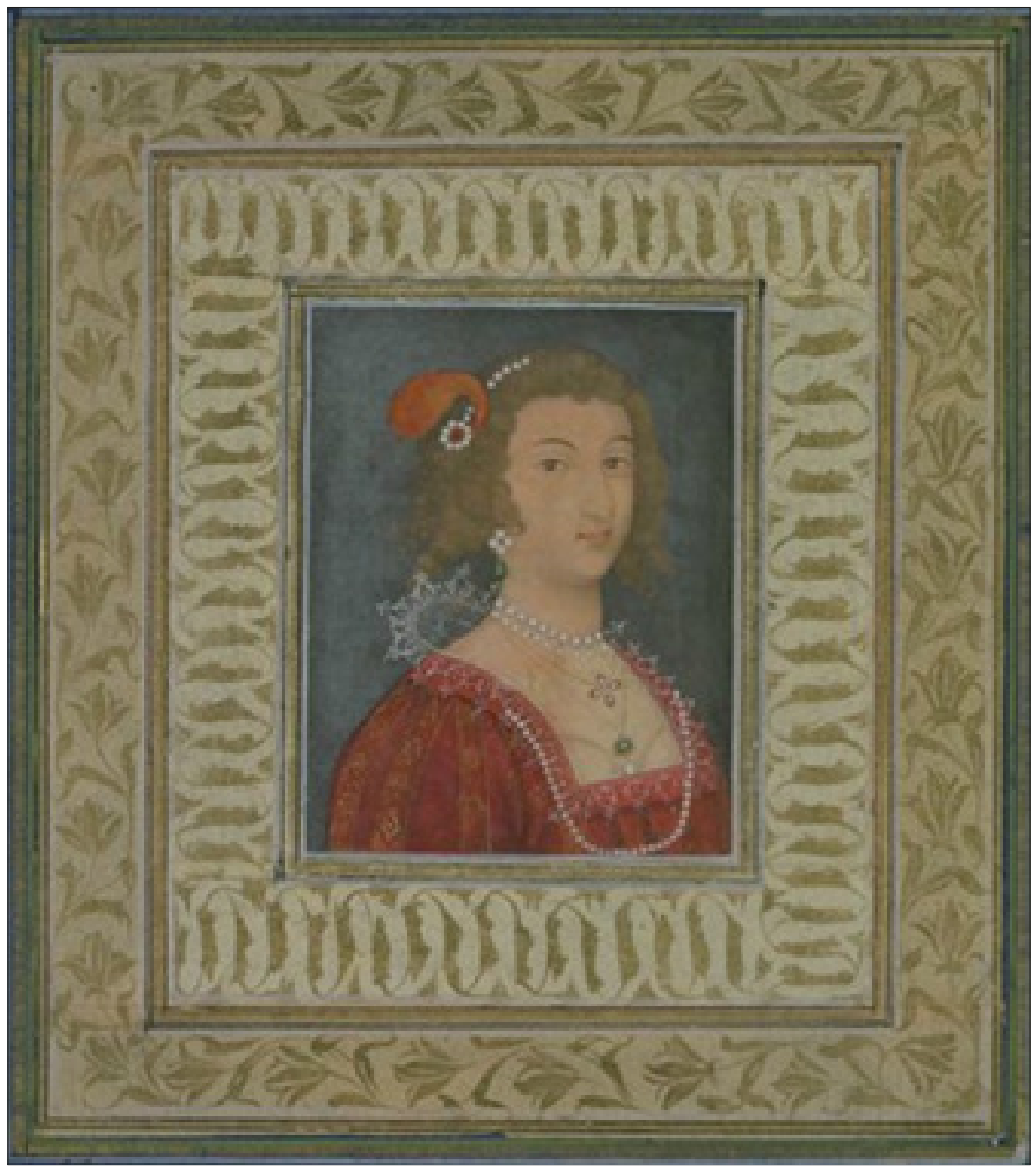

4. Lady Shirley, szkoła mogolska, ok. 1650 C Victoria and Albert Museum, London (IM.8-1913) 


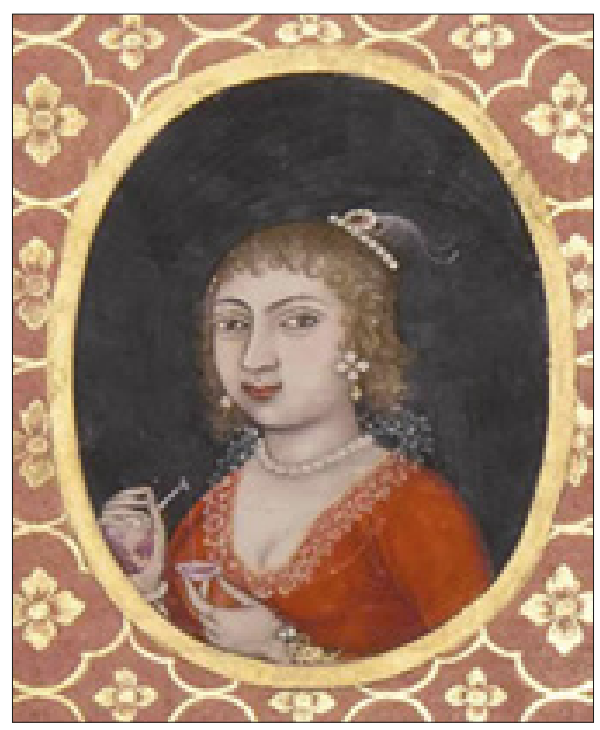

5. Portret damy, szkoła mogolska, 2 poł. XVIII w., zbiory prywatne 


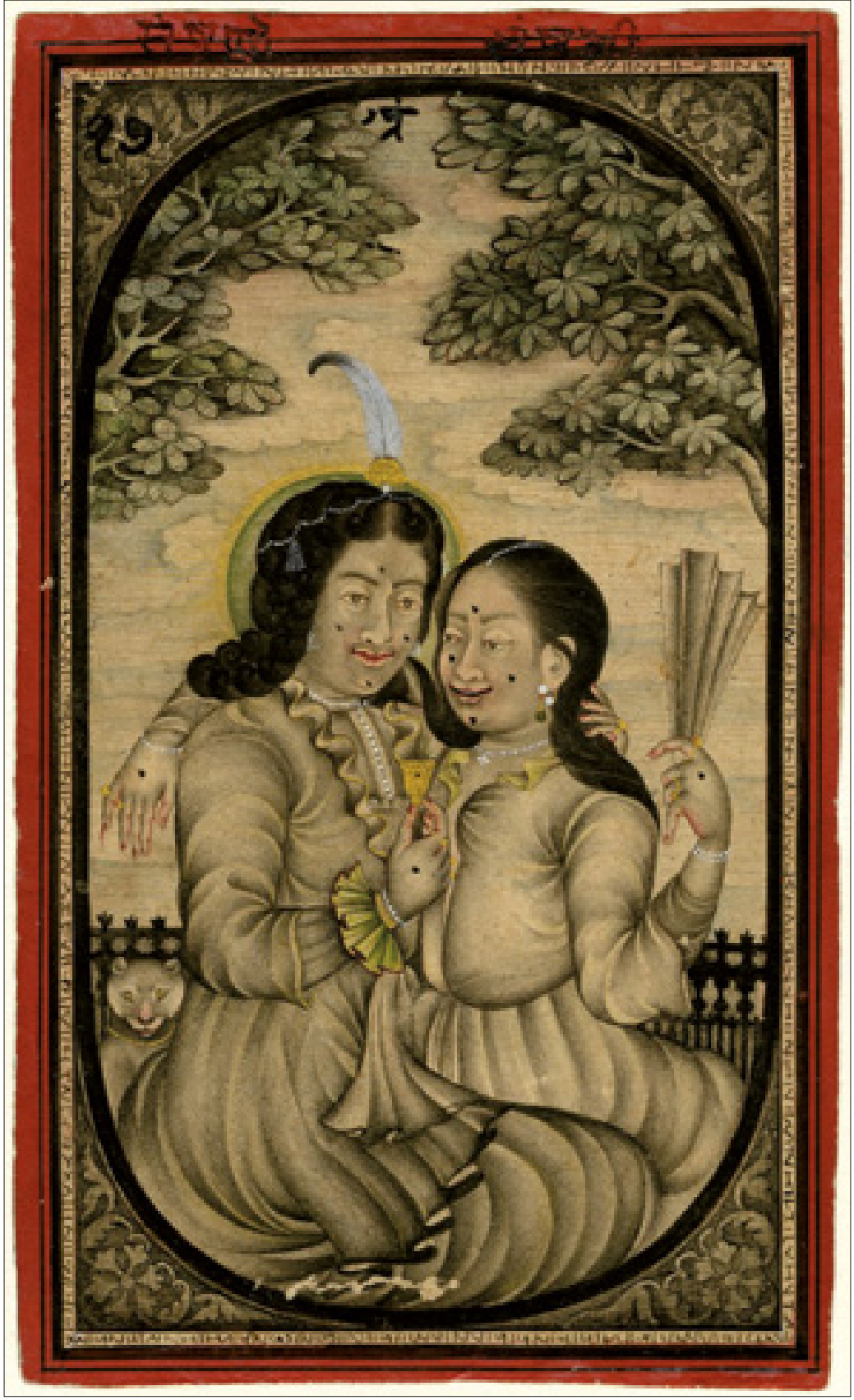

6. Kochankowie, Udaipur, ok. 1720, (C) Trustees of the British Museum (1956,0714,0.27) 


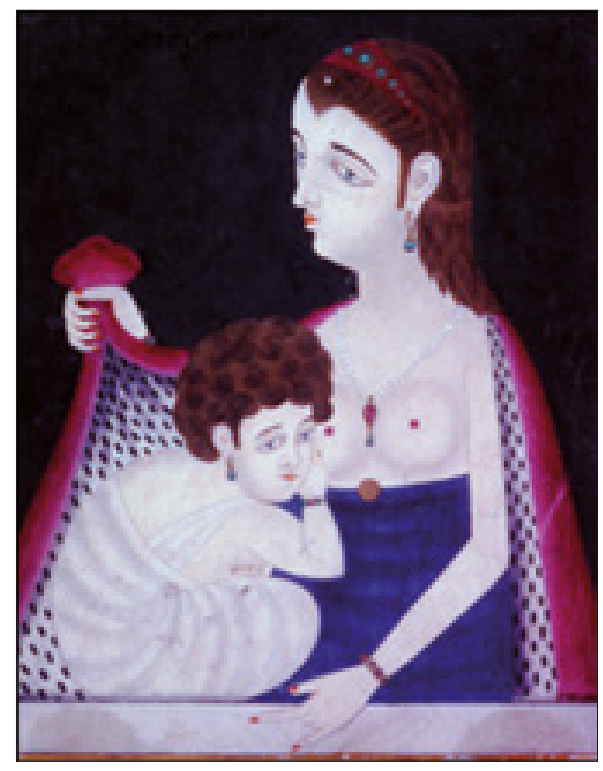

7. Wiktoria Maharani, XIX w., zbiory prywatne

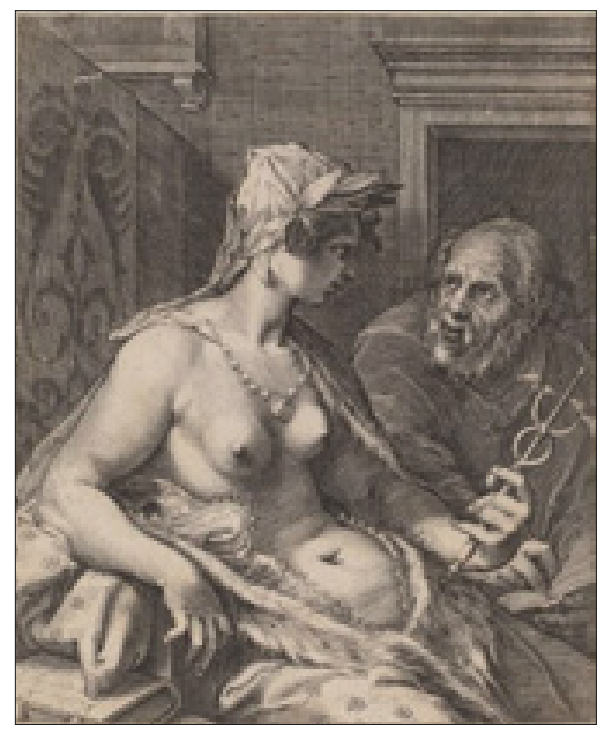

8. Poezja, Cornelius Jacobsz Drebbel (I572-I634), Museum of Fine Arts, Boston (B1302) 


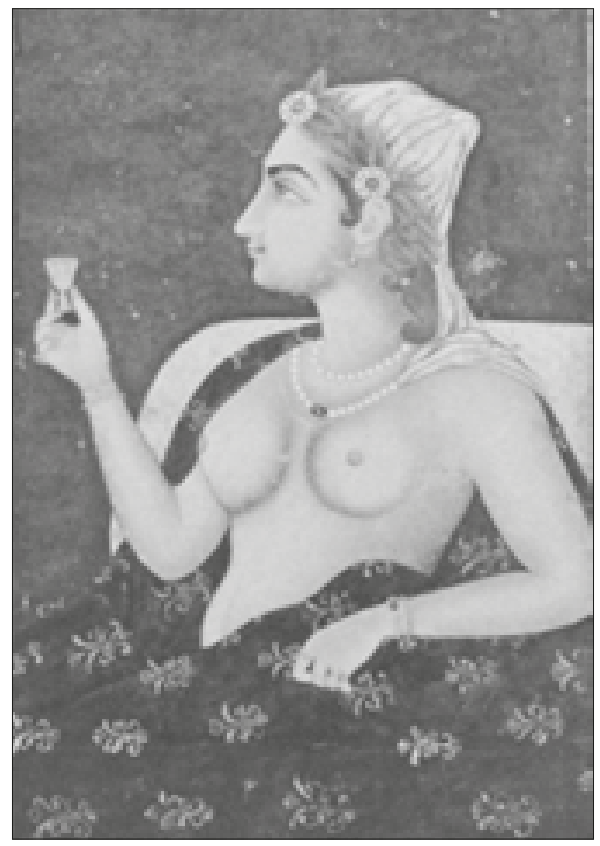

9. Muraqq Gaulshan (fragment), 1 poł. XVII w., Gulshan Library, Tehran (Milo Cleveland Beach, „The Gulshan Album and Its European Sources", Bulletin of the Museum of Fine Arts, vol. 63, no. 332 (1965), s. 87) 


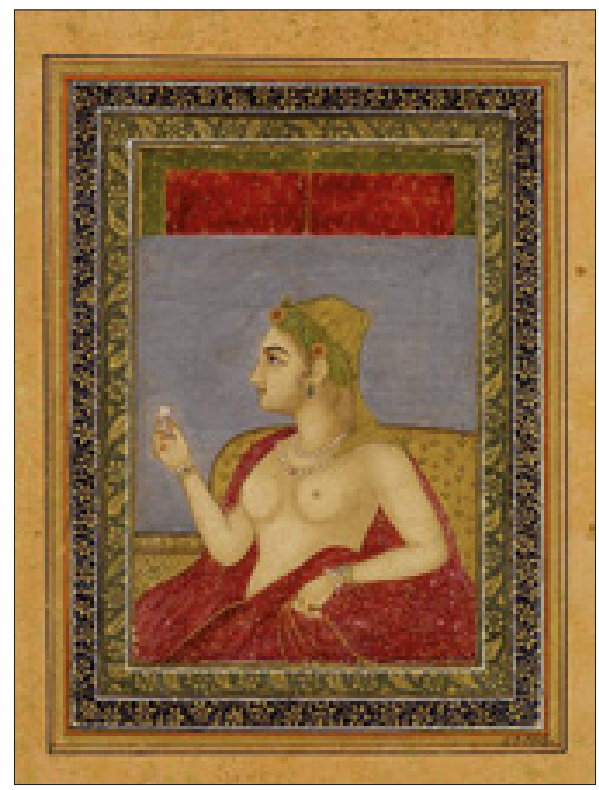

10. Portret kobiety, szkoła mogolska, ok. 1700 r. (C) Victoria and Albert Museum, London (IS.259-1952) 
[242]

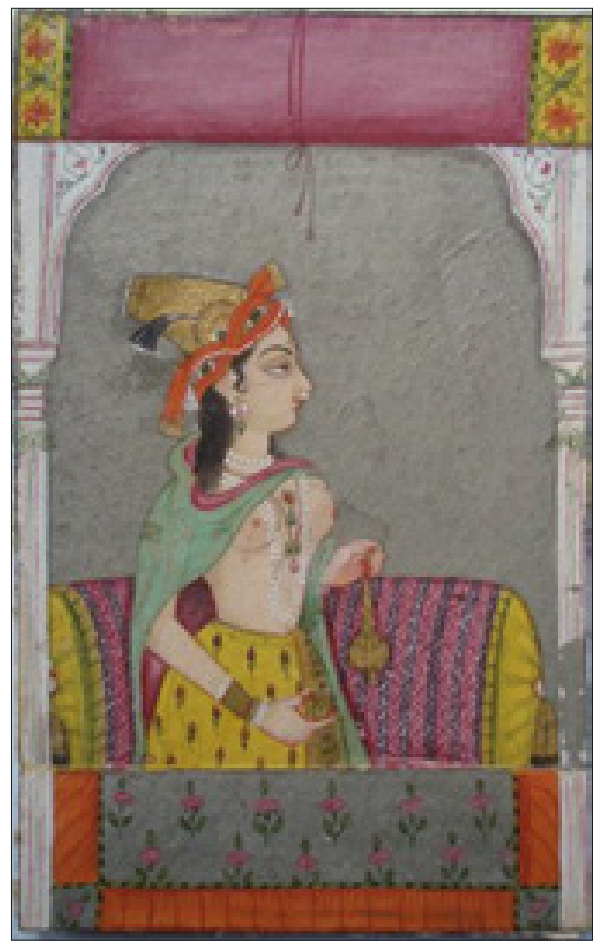

11. Kurtyzana, Bikaner, ok. 1770, zbiory prywatne

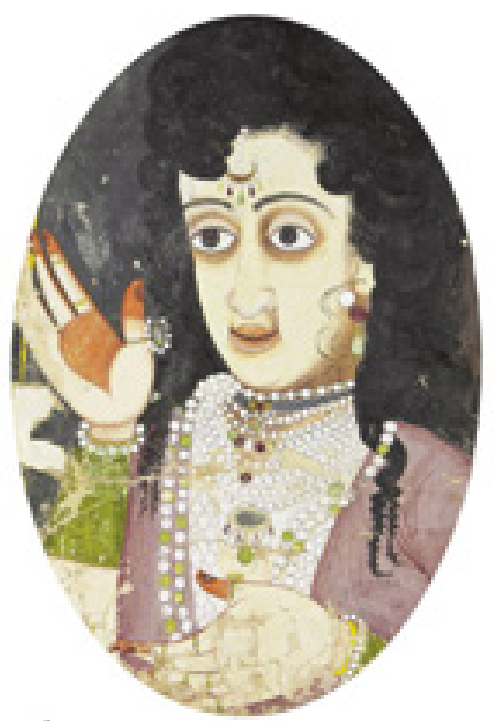

12. Portret kobiety, Mewar, kon. XVIII w., zbiory prywatne 